Article

\title{
Preparation and Characterization of Poly(ethyl hydrazide)-Grafted Oil Palm Empty Fruit Bunch Fibre for the Removal of Cu(II) Ions from an Aqueous Environment
}

\author{
Ili Syazana Johari ${ }^{1}$, Nor Azah Yusof ${ }^{1,2, *}$, Md Jelas Haron ${ }^{3}$ and Siti Mariam Mohd Nor ${ }^{1}$ \\ 1 Department of Chemistry, Faculty of Science, Universiti Putra Malaysia, 43400 Serdang, Selangor, \\ Malaysia; E-Mails: ili@putra.upm.edu.my (I.S.J.); mariam@science.upm.edu.my (S.M.M.N.) \\ 2 Institute of Advanced Technology, Universiti Putra Malaysia, 43400 Serdang, Selangor, Malaysia \\ 3 Chemistry Unit, Centre of Foundation Studies for Agricultural Science, Universiti Putra Malaysia, \\ 43400 Serdang, Selangor, Malaysia; E-Mail: mdjelas@gmail.com
}

* Author to whom correspondence should be addressed; E-Mail: azahy@upm.edu.my;

Tel.: +603-8946-6782; Fax: +603-8943-5380.

Received: 1 March 2013; in revised form: 26 June 2013 / Accepted: 27 June 2013 /

Published: 18 July 2013

\begin{abstract}
Poly(ethyl hydrazide)-grafted oil palm empty fruit bunch fibre (peh-g-opefb) was successfully prepared by heating poly(methyl acrylate)-grafted opefb (pma-g-opefb) at $60{ }^{\circ} \mathrm{C}$ for $4 \mathrm{~h}$ with a solution of hydrazine hydrate $(15 \% \mathrm{v} / \mathrm{v})$ in ethanol. The Fourier transform infrared spectrum of the product shows a secondary amine peak at $3267 \mathrm{~cm}^{-1}$, with amide carbonyl peaks at $1729 \mathrm{~cm}^{-1}$ and $1643 \mathrm{~cm}^{-1}$. The chelating ability of peh-g-opefb was tested with copper ion in aqueous solution. A batch adsorption study revealed that maximum adsorption of copper ion was achieved at $\mathrm{pH}$ 5. An isotherm study showed the adsorption follows a Langmuir model, with a maximum adsorption capacity of $43.48 \mathrm{mg} \mathrm{g}^{-1}$ at $25{ }^{\circ} \mathrm{C}$. A kinetic study showed that the adsorption of copper ion rapidly reaches equilibrium and follows a pseudo-second-order kinetic model, with a constant rate of $7.02 \times 10^{-4} \mathrm{~g} \mathrm{mg}^{-1} \mathrm{~min}^{-1}$ at $25^{\circ} \mathrm{C}$. The Gibbs free energy, $\Delta \mathrm{G}^{0}$, value is negative, indicating a spontaneous sorption process. Entropy, $\Delta \mathrm{S}^{0}$, gives a positive value, indicating that the system is becoming increasingly disordered after the adsorption of copper ion. A positive enthalpy value, $\Delta \mathrm{H}^{0}$, shows that the endothermic process takes place during the adsorption and is more favourable at high temperatures.
\end{abstract}

Keywords: copper; poly(ethyl hydrazide); isotherm; kinetic 


\section{Introduction}

In recent years, with industrial activity rapidly expanding the discharge of industrial toxic metals into waterways has become a serious problem. Activities such as mining, metal finishing, electroplating, welding, and alloy manufacturing have been proven to be major sources of heavy metal releases into the environment [1]. An increase in copper in our bodies, for example, will irritate the central nervous system and corrode the gastrointestinal system, accompanied by depression, harming the capillary, hepatic, and renal functions and causing other malfunctions [2]. Moreover, copper, mostly discharged in the form of cupric ion [Cu(II)] has been listed as a priority pollutant by the US Environmental Protection Agency (EPA) [3].

Adsorption using chelating fibres is a popular technique nowadays for heavy metal removal [4] due to its simplicity, low cost, and ability to remove elements efficiently, even at trace levels [5]. The application of biosorption to environmental treatment has become a significant research area in the past 10 years. The biosorption of heavy metals from aqueous solutions is a relatively new process that has been proven to be very promising in the removal of contaminants from aqueous effluents. In adsorption, the type of adsorbent is an important factor in effectively removing metal ions. Synthetic resins that can form chelate structures with metal ions have often been used by many researchers for the removal and recovery of heavy metal ions from wastewater. In many cases, petroleum-based synthetic copolymers such as styrene-divinylbenzene have been utilized, but most petroleum-based synthetic polymers resin are in bead form and are neither renewable nor biodegradable. Biomass, which is more biodegradable, could thus be an economical alternative material for heavy metal removal from wastewater. Oil palm empty fruit bunch (opefb), rubber wood, and kenaf are several types of cheap biomass fibre available in Malaysia. Malaysia is one of the World's major oil palm producers and opefb is one of the major solid wastes left after the oil extraction process; therefore the expected solid waste generated is enough to cause a waste management problem. For this reason, it is worth exploring and modifying agricultural materials for metal adsorption purposes.

In this study, poly(methyl acrylate)-grafted opefb (pma-g-opefb) obtained from the graft copolymerization process was modified to yield poly(ethyl hydrazide)-grafted opefb (peh-g-opefb), which was then used as an adsorbent for the removal of copper from aqueous solutions.

\section{Results and Discussion}

\subsection{Graft Copolymerization of Methyl Acrylate onto Opefb}

Hydrogen peroxide was used in a graft copolymerization reaction as an initiator, while ferrous ammonium sulphate was used as a co-initiator. The addition of $\mathrm{Fe}^{2+}$ in the reaction produces a hydroxyl radicals during the decomposition of hydrogen peroxide, which leads to the initiation of fibre macroradicals [6]. The macroradicals formed were then reacted with methyl acrylate to form the copolymer poly(methyl acrylate). The process was terminated when two radicals combined and formed a homopolymer and a copolymer. The opefb was successfully grafted with methyl acrylate to obtain pma-g-opefb, with a $117.24 \%$ grafting percentage. Scheme 1 illustrates the mechanism of the graft copolymerization process involving methyl acrylate as a monomer and opefb as proposed [6]. The peh-g-opefb was then obtained by reaction of the pma-g-opefb with hydrazine hydrate. The 
presence of hydrazide functional group in peh-g-opefb provides better chelation involving the carbonyl oxygen and nitrogen atom with copper ions [7] hence has higher adsorption capacity compared to the unmodified opefb.

Scheme 1. Proposed reaction mechanism in the graft copolymerization of methyl acrylate onto opefb [6].

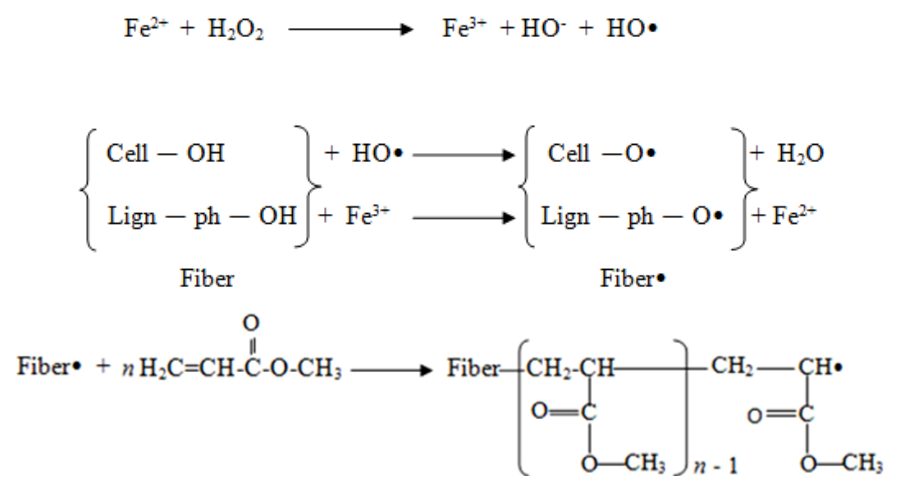

\subsection{Characterization of Peh-g-opefb}

Fourier Transform Infrared Analysis

Figure 1 shows the FTIR spectra of all types of opefb, pma-g-opefb, and peh-g-opefb. A broad absorption band appears at around 3,500-3,200 $\mathrm{cm}^{-1}$ in the opefb, indicating that the $\mathrm{O}-\mathrm{H}$ stretching is attributable to the hydroxyl groups of cellulose, absorbed water, hemicelluloses, and lignin [6]. In peh-g-opefb, a broad absorption band appears at about $3300 \mathrm{~cm}^{-1}$ and $3100 \mathrm{~cm}^{-1}$, indicating $\mathrm{N}-\mathrm{H}$ stretching from the amine group, consistent with the $\mathrm{N}-\mathrm{H}$ stretching observed for polyacryl-amidrazonehydrazide, which appears at $3319 \mathrm{~cm}^{-1}$ and $3180 \mathrm{~cm}^{-1}$ [3].

Figure 1. The FTIR spectra for opefb, pma-g-opefb, and peh-g-opefb.

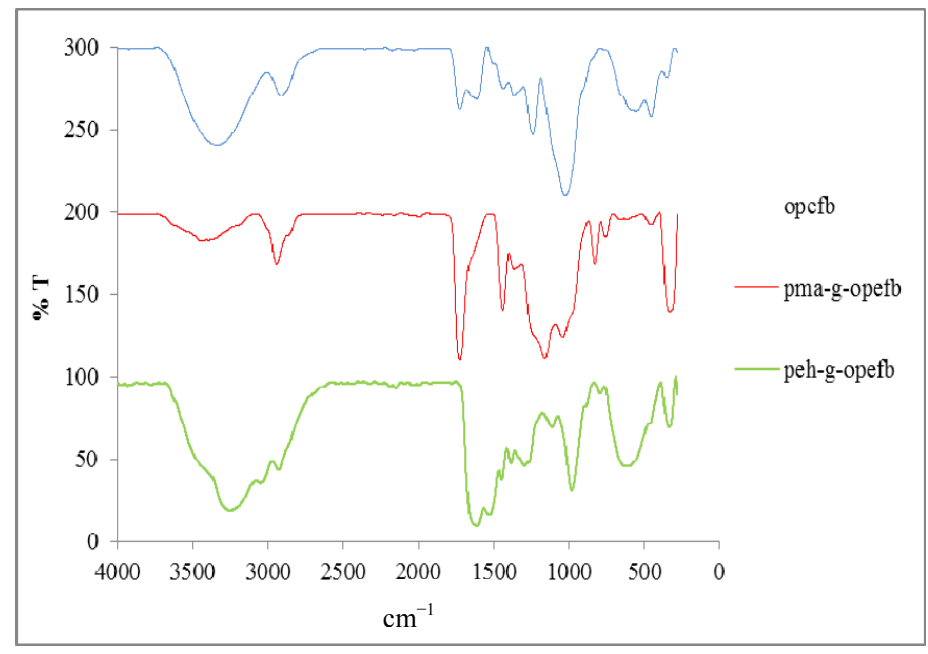

The FTIR spectrum of pma-g-opefb shows one absorption band, observed at $1741 \mathrm{~cm}^{-1}$, which corresponds to carbonyl stretching of the ester functional groups of the poly(methyl acrylate). When the pma-g-opefb is converted to peh-g-opefb, the carbonyl ester absorption band at $1741 \mathrm{~cm}^{-1}$ disappears and a new absorption band appears around $1650 \mathrm{~cm}^{-1}$, representing carbonyl stretching 
from the amide in peh-g-opefb, which may be due to the conversion of the majority of the ester group to hydrazide [8]. Furthermore, another absorption band observed at about $1580 \mathrm{~cm}^{-1}$ indicates $\mathrm{N}-\mathrm{H}$ bending in peh-g-opefb. This result is in agreement with the results of Liu et al., who reported the presence of an N-H bending absorption band around $1560 \mathrm{~cm}^{-1}$ in poly(acrylaminophosphonic-carboxylhydrazide) [4]. The existence of an absorption band around $2900 \mathrm{~cm}^{-1}$ in all grafted opefb, ungrafted opefb, and peh-g-opefb may be due to $\mathrm{C}-\mathrm{H}$ stretching from cellulose and lignin [9].

\subsection{Copper (II) Ion Adsorption Study}

\subsubsection{Effect of $\mathrm{pH}$}

Figure 2 shows that a greater uptake of copper ion was achieved at a $\mathrm{pH}$ range of 3-5 with an adsorption capacity of $21.02 \mathrm{mg} \mathrm{g}^{-1}$. The graph shows that the adsorption capacity for copper ion increased as the $\mathrm{pH}$ increased. The lower uptake of copper ions in acidic media $(\mathrm{pH} 1$ and $\mathrm{pH} 2)$ may be attributed to the competition of copper ions and protons with the protonated amine groups, which leads to strong electrostatic repulsion [10-13]. Hence, the protonated amine group obtained in the lower $\mathrm{pH}$ medium reduces the number of hydrazide binding sites available for adsorption with copper ions. As the $\mathrm{pH}$ increases, the hydrazides on the adsorbent surface mainly turn into dissociated forms so that the uptake of copper ions increases due to the greater numbers of negatively charged binding sites [13-16]. As the solution $\mathrm{pH}$ increased to $\mathrm{pH} 6$, the adsorption capacity was found to decrease due to the formation of copper hydroxide in solution [17].

Figure 2. Adsorption capacity of peh-g-opefb towards copper ion at different $\mathrm{pH}$ values.

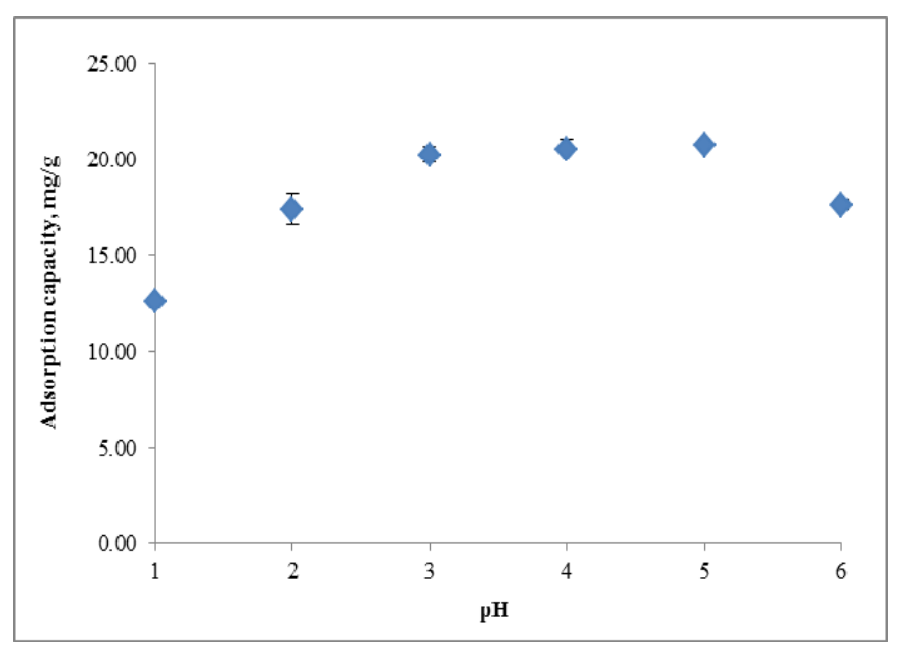

\subsubsection{Effect of Initial Concentration}

Figure 3 show that the adsorption capacity for copper ions increases from $9.95 \mathrm{mg} \mathrm{g}^{-1}$ to $52.98 \mathrm{mg} \mathrm{g}^{-1}$ at $25{ }^{\circ} \mathrm{C}$, from $10.23 \mathrm{mg} \mathrm{g}^{-1}$ to $65.41 \mathrm{mg} \mathrm{g}^{-1}$ at $50{ }^{\circ} \mathrm{C}$, and from $10.64 \mathrm{mg} \mathrm{g}^{-1}$ to $72.89 \mathrm{mg} \mathrm{g}^{-1}$ at $75^{\circ} \mathrm{C}$ as the initial concentration increases from $50 \mathrm{mg} \mathrm{L}^{-1}$ to $800 \mathrm{mg} \mathrm{L}^{-1}$. However, the percentage removal of copper ions by peh-g-opefb reveals a reversed trend. For a fixed dosage of peh-g-opefb and a fixed-pH copper ion solution, the percentage removal of copper decreases from $97.38 \%$ to $14.4 \%$ at $25{ }^{\circ} \mathrm{C}$, 
from $99.29 \%$ to $25.21 \%$ at $50{ }^{\circ} \mathrm{C}$, and from $96.97 \%$ to $34.68 \%$ at $75{ }^{\circ} \mathrm{C}$ as the initial concentration of metal ions increases.

The initial concentrations of metal ions act as an important driving force to be overcome the total mass transfer resistance of metal ions between the aqueous and solid phases $[16,18,19]$. The adsorption capacity increases with higher concentrations, suggesting that the increased amount of metal ions in the solution has enhanced the interactions between metal ions and the active sites on the adsorbent surface [20,21]. However, as the concentration of copper increases, the percentage removal decreases, indicating that peh-g-opefb tends to become saturated, yielding no further sites available for adsorption [2,22].

Figure 3. Effect of different initial concentrations at different temperatures on the adsorption capacity of peh-g-opefb for copper ion.

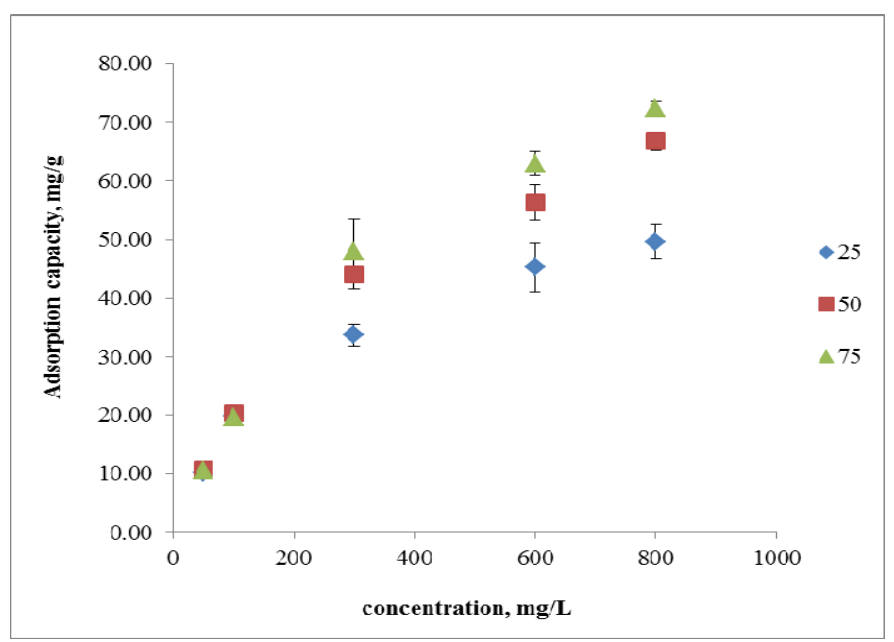

\subsubsection{Adsorption Isotherms}

Isotherm studies are fundamental in determining the nature of adsorption between an adsorbent and metal ions. They indicate how the metal ions are distributed between adsorbents and metal solutions in the equilibrium phase [2]. To illustrate the data obtained, Langmuir and Freundlich isotherm models were proposed for the adsorption of solute on a solid surface.

The Langmuir isotherm model assumes a homogeneous surface and a constant sorption potential and can be expressed with the following equation:

$$
\mathrm{C}_{\mathrm{e}} / \mathrm{q}_{\mathrm{e}}=\mathrm{C}_{\mathrm{e}} / \mathrm{Q}_{\mathrm{o}}+1 / \mathrm{Q}_{\mathrm{o}} \mathrm{b}
$$

where $\mathrm{Q}_{0}\left(\mathrm{mg} \mathrm{g}^{-1}\right)$ is the maximum adsorption at the monolayer, $\mathrm{C}_{\mathrm{e}}\left(\mathrm{mg} \mathrm{L}^{-1}\right)$ is the equilibrium concentration, $\mathrm{q}_{\mathrm{e}}\left(\mathrm{mg} \mathrm{g}^{-1}\right)$ is the amount of copper adsorbed at equilibrium concentration, and $\mathrm{b}\left(\mathrm{L} \mathrm{g}^{-1}\right)$ is the Langmuir constant.

The Freundlich isotherm model deals with a heterogeneous surface, with assumption that different sites with several adsorption energies are involved, and can be expressed as follows:

$$
\log \mathrm{q}_{\mathrm{e}}=\log \mathrm{K}_{\mathrm{F}}+\log \mathrm{C}_{\mathrm{e}} / \mathrm{n}
$$

where $\mathrm{K}_{\mathrm{F}}$ is the Freundlich constant $\left(\mathrm{mg} \mathrm{g}^{-1}\right)$ that indicates sorption capacity and $\mathrm{n}$ is the Freundlich constant that indicates adsorption intensity. 
Table 1 shows the Langmuir and Freundlich isotherm data of adsorption of copper ion onto peh-g-opefb. From the $\mathrm{R}^{2}$ values, it can be concluded that the equilibrium data of copper adsorption fit the Langmuir isotherm model better than the Freundlich model, with correlation coefficients of 0.9645 , 0.9863 , and 0.9849 at 25,50 , and $75{ }^{\circ} \mathrm{C}$, respectively. Therefore, it can be concluded that copper adsorption onto peh-g-opefb involves a monolayer adsorption with equivalent active sites and a uniform adsorbent surface. Hence, the adsorbed copper or nickel ions do not compete with each other and equilibrium is established where all the adsorbed ions are in contact with the adsorbent's surface [23].

Table 1. Langmuir and Freundlich isotherm constants, maximum adsorption capacities, $\mathrm{Q}_{\max }$, correlation coefficients, and $\mathrm{R}^{2}$ values for copper adsorption at various temperatures.

\begin{tabular}{|c|c|c|c|c|c|c|c|}
\hline \multicolumn{5}{|c|}{ Langmuir isotherm } & \multicolumn{3}{|c|}{ Freundlich isotherm } \\
\hline Temp. $\left({ }^{\circ} \mathrm{C}\right)$ & $Q_{\max }\left(\mathrm{mg} \mathrm{g}^{-1}\right)$ & b $\left(\mathrm{L} \mathrm{mg}^{-1}\right)$ & $\mathbf{R}^{2}$ & $\mathbf{R}_{\mathbf{L}}$ & $K_{F}\left(\mathrm{mg} \mathrm{g}^{-1}\right)$ & $\mathbf{n}$ & $\mathbf{R}^{2}$ \\
\hline 25 & 43.48 & 0.3382 & 0.9645 & 0.0161 & 10.87 & 4.4603 & 0.9350 \\
\hline 50 & 59.17 & 0.0817 & 0.9863 & 0.0601 & 13.16 & 3.7078 & 0.9990 \\
\hline 75 & 76.92 & 0.0289 & 0.9849 & 0.1460 & 14.02 & 4.3687 & 0.9648 \\
\hline
\end{tabular}

The maximum adsorption capacities of peh-g-opefb with other natural adsorbents are listed in Table 2. Among the studies listed in Table 2, Haron et al. [9] also used modified opefb as an adsorbent. The adsorption capacity for copper ion of poly(hydroxamic acid)-grafted opefb is higher than that of peh-grafted opefb obtained in this study. The differences in uptake capacities may be due to the properties of biosorbent materials, such as structure, functional group and surface area, and solution chemistry [24].

Table 2. Maximum adsorption capacities $\left(\mathrm{Q}_{\max }\right)$ for copper of other low-cost biosorbents.

\begin{tabular}{ccc}
\hline Adsorbent & $\mathbf{q}_{\mathbf{m a x}}\left(\mathbf{m g ~ g}^{-\mathbf{1}}\right)$ & References \\
$\mathbf{C u}(\mathbf{I I})$ & 43.48 & present study \\
\hline Opefb (grafted with methyl acrylate and heated with hydrazine hydrate) & 7.72 & {$[19]$} \\
Rape straw & 9.95 & {$[23]$} \\
Uncaria gambir (polymerized by formaldehyde) & 20.00 & {$[17]$} \\
Cashew nut shell & 74.10 & {$[9]$} \\
Opefb (grafted with methyl acrylate and reacted with & 14.97 & {$[12]$} \\
hydroxylammonium chloride) & 9.59 & \\
Rubber leaf powder & 17.42 & {$[16]$} \\
Lentil shell & 2.95 & \\
Wheat shell & 3.6 & {$[25]$} \\
Rice shell & 13.06 & {$[26]$} \\
opefb & &
\end{tabular}

The essential features of the Langmuir isotherm can be expressed in terms of a dimensionless constant separation factor, $\mathrm{R}_{\mathrm{L}}$, used to predict whether the sorption system is favourable or unfavourable in a batch adsorption process. Using the $b$ value obtained from the Langmuir isotherm equation, one can calculate the separation factor, $\mathrm{R}_{\mathrm{L}}$, using the following equation: 


$$
\mathrm{R}_{\mathrm{L}}=\left[1 / 1+\mathrm{b} \mathrm{C}_{0}\right]
$$

where $\mathrm{C}_{0}$ is the initial concentration of copper ion $\left(\mathrm{mg} \mathrm{L}^{-1}\right)$ and $\mathrm{b}$ is the Langmuir constant $\left(\mathrm{L} \mathrm{mg}^{-1}\right)$.

The data show that the $\mathrm{R}_{\mathrm{L}}$ values for copper adsorption onto peh-g-opefb are favourable at all temperatures, for all $\mathrm{R}_{\mathrm{L}}$ values between zero and one. In addition, the $n$ value obtained from the Freundlich equation can also indicate the favourability of the adsorption process: values of $n$ from two to 10 are good, values of one to two denote moderate difficulty, and values less than one are poor [27]. Based on the data the values of $n$ for copper adsorption onto peh-g-opefb at all temperatures studied were in the range of two to 10 , indicating a favourable adsorption process and thus in consistent with the $\mathrm{R}_{\mathrm{L}}$ values obtained from the Langmuir equation.

\subsubsection{Adsorption Thermodynamics}

Thermodynamic parameters such as changes in enthalpy $\left(\Delta \mathrm{H}^{0}\right)$, in entropy $\left(\Delta \mathrm{S}^{0}\right)$, and in free energy $\left(\Delta \mathrm{G}^{0}\right)$ are important to determining the spontaneity of the adsorption process. Entropy, $\Delta \mathrm{S}^{0}$, and enthalpy, $\Delta \mathrm{H}^{0}$, values are obtained from the slopes and intercepts of the linear regression of the plot $\ln$ $\mathrm{K}_{\mathrm{D}}$ versus $1 / \mathrm{T}$, whereas the free energy is determined using the following equation:

$$
\Delta \mathrm{G}^{0}=\Delta \mathrm{H}^{\mathrm{0}}-\mathrm{T} \Delta \mathrm{S}^{\mathrm{O}}
$$

where $\Delta \mathrm{G}^{0}$ is free energy $\left(\mathrm{kJ} \mathrm{mol}^{-1}\right), \Delta \mathrm{H}^{0}$ is standard enthalpy $\left(\mathrm{kJ} \mathrm{mol}^{-1}\right), \Delta \mathrm{S}^{0}$ is standard entropy $\left(\mathrm{J} \mathrm{mol}^{-1} \mathrm{~K}^{-1}\right)$, and $\mathrm{T}$ is temperature $(\mathrm{K})$.

The summarized values of all the thermodynamic parameters for copper adsorption are tabulated in Table 3.

\begin{tabular}{|c|c|c|c|}
\hline Temp, K & $\begin{array}{c}\text { E nthalpy, } \Delta \mathbf{H}^{\mathbf{0}} \\
\left(\mathrm{kJ} \mathrm{mol}^{-1}\right)\end{array}$ & $\begin{array}{l}\text { Entropy, } \Delta \mathrm{S}^{0} \\
\left(\mathrm{~J} \mathrm{~mol}^{-1} \mathbf{K}^{-1}\right)\end{array}$ & $\begin{array}{c}\text { Free energy, }-\Delta \mathbf{G}^{\mathbf{0}} \\
\left(\mathrm{kJ} \mathrm{mol}^{-1}\right)\end{array}$ \\
\hline 298 & & & 5.19 \\
\hline 323 & 20.96 & 87.75 & 7.38 \\
\hline 348 & & & 9.57 \\
\hline
\end{tabular}

Table 3. Thermodynamic parameters for copper adsorption by peh-g-opefb.

The negative values of free energy, $\Delta \mathrm{G}^{0}$, indicate the spontaneous nature of the adsorption process. The $\Delta \mathrm{G}^{0}$ values for copper adsorption increase as the temperature increases, which leads to higher adsorption capacities [28] and increases the feasibility of adsorption at higher temperatures [29]. In other words, more negative values reflect a more energetically favourable adsorption process [30]. The positive value of entropy, $\Delta \mathrm{S}^{0}$, indicates that the system is becoming more disordered and increasingly random at the solid-solution interface during adsorption [31]. The positive value of enthalpy, $\Delta \mathrm{H}^{\circ}$, shows that the adsorption of copper ions onto peh-g-opefb involves an endothermic adsorption process.

\subsubsection{Adsorption Kinetics}

Figure 4 shows that the adsorption of copper rapidly increases with increasing contact time from zero to $120 \mathrm{~min}$ and then gradually increases before reaching an equilibrium stage at approximately 480 min. 
Figure 4. Adsorption capacity for copper ion by peh-grafted opefb for different contact times.

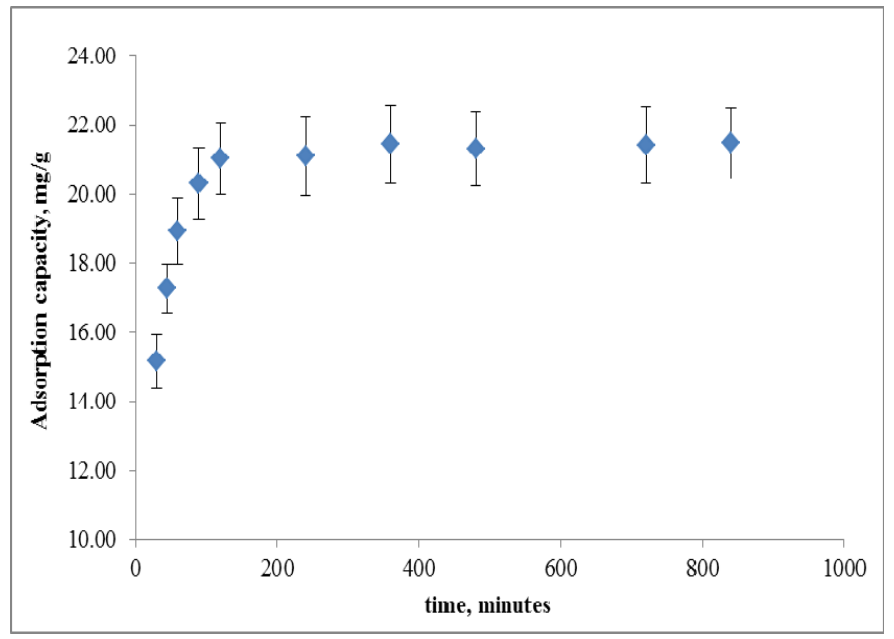

To determine the mechanism and constant characteristics of sorption, two kinetic models were applied to the experimental data: a pseudo-first-order kinetic model and a pseudo-second-order kinetic model. The pseudo-first-order kinetic model is expressed as the following equation:

$$
\ln \left(\mathrm{q}_{\mathrm{e}}-\mathrm{q}_{\mathrm{t}}\right)=\ln \mathrm{q}_{\mathrm{e}}-\mathrm{k}_{1} \mathrm{t} / 2.303
$$

where $\mathrm{q}_{\mathrm{t}}$ is the amount of adsorbate $\left(\mathrm{mg} \mathrm{g}^{-1}\right)$ on the sorbent at time $\mathrm{t}, \mathrm{q}_{\mathrm{e}}$ is the amount of adsorbate $\left(\mathrm{mg} \mathrm{g}^{-1}\right)$ on the sorbent at equilibrium, and $\mathrm{k}_{1}$ is the first-order rate constant $\left(\mathrm{min}^{-1}\right)$.

Ho and McKay [32] proposed the pseudo-second-order kinetic model based on the assumption that the adsorption process follows second-order chemisorption. The pseudo-second-order kinetic model can be written as the following equation:

$$
\mathrm{t} / \mathrm{q}_{\mathrm{t}}=1 / \mathrm{k}_{2} \mathrm{q}_{\mathrm{e}}^{2}+\mathrm{t} / \mathrm{q}_{\mathrm{e}}
$$

where $\mathrm{q}_{\mathrm{t}}$ is the amount of adsorbate $\left(\mathrm{mg} \mathrm{g}^{-1}\right)$ on the sorbent at time $\mathrm{t}, \mathrm{q}_{\mathrm{e}}$ is the amount of adsorbate $\left(\mathrm{mg} \mathrm{g}^{-1}\right)$ on the sorbent at equilibrium, and $\mathrm{k}_{2}$ is the second-order rate constant $\left[\mathrm{g}(\mathrm{mg} \mathrm{min})^{-1}\right]$.

The data show that the adsorption capacities, $\mathrm{q}_{\mathrm{e}}$, are much lower than the experimental $\mathrm{q}_{\mathrm{e}}$ for the pseudo-first-order model for copper adsorption, indicating that copper adsorption does not occur exclusively with one site per ion [18,28]. On the other hand, pseudo-second-order kinetic models yield $\mathrm{q}_{\mathrm{e}}$ values close to the experimental $\mathrm{q}_{\mathrm{e}}$ for copper adsorption onto peh-g-opefb, with $\mathrm{R}^{2}$ values of 0.99 , confirming the applicability of a pseudo-second-order kinetic model for adsorption by peh-g-opefb.

It is also can be concluded that the overall rate of copper adsorption is controlled by chemical processes [18]. This result is in agreement with the isotherm data reported earlier. Table 4 summarizes the kinetic data for copper adsorption onto peh-g-opefb.

Table 4. Comparison of pseudo-first-order and pseudo-second-order rate constants $\mathrm{k}$ and

\begin{tabular}{|c|c|c|c|c|}
\hline Kinetic models & $\begin{array}{c}q_{e} \exp \\
\left(\mathrm{mg} \mathrm{g}^{-1}\right)\end{array}$ & $\begin{array}{l}\text { Rate constant, } \mathrm{k}_{1}\left(\mathrm{~min}^{-1}\right), \\
\mathrm{k}_{2}\left(\mathrm{~g} \mathrm{mg}^{-1} \mathrm{~min}^{-1}\right)\left(\times 10^{-3}\right)\end{array}$ & $\begin{array}{l}\text { qe calc. } \\
\left(\mathrm{mg} \mathrm{g}^{-1}\right)\end{array}$ & $\begin{array}{c}\text { Correlation } \\
\text { coefficient, } \mathbf{R}^{2} \\
\end{array}$ \\
\hline Pseudo-first order & \multirow{2}{*}{20.33} & 3.90 & 4.195 & 0.8952 \\
\hline Pseudo-second order & & 2.93 & 20.79 & 0.9999 \\
\hline
\end{tabular}
calculated $\left(\mathrm{q}_{\mathrm{e}}{ }^{\mathrm{a}}\right)$ and experimental $\left(\mathrm{q}_{\mathrm{e}}{ }^{\mathrm{b}}\right)$ adsorption capacity values. 


\section{Experimental}

\subsection{Instruments and Apparatus}

An inductively coupled plasma-optical emission spectrometer (ICP-OES; Perkin Elmer Instruments, Waltham, MA, USA) and an FTIR spectrophotometer (Perkin Elmer) were used.

\subsection{Materials and Reagents}

The Wood Chemistry Division of the Forest Research Institute Malaysia (FRIM) provided the opefb fibre. The opefb was soaked with distilled water for $24 \mathrm{~h}$ and washed with hot water and acetone to remove impurities. Then the fibre was dried in an oven at $60{ }^{\circ} \mathrm{C}$. Methyl acrylate was purchased from Acros Organics (Waltham, MA, USA). Activated alumina used for the methyl acrylate purification was purchased from Merck (Darmstadt, Germany). Hydrogen peroxide, 30\% from Riedel-de-Hazen (Seelze, Germany); ammonium ferrous sulphate from Fluka (Switzerland); Hydrazine hydrate, 100\% from Merck (Hohenbrunn, Germany); Absolute ethanol (Merck), and Copper (II) sulphate (HmbG Chemicals) were used as received.

\subsection{Graft Copolymerization of Pma-g-Opefb Chelating Fibres}

The opefb fibre was ground with a stainless steel grinder, washed with hot water, rinsed with acetone, and dried in an oven at $60{ }^{\circ} \mathrm{C}$. The fibre was then sieved using a 180 -micron sieve to obtain a homogeneous fibre size. About $30.0 \mathrm{~g}$ of opefb was suspended under a nitrogen atmosphere in $500 \mathrm{~mL}$ of distilled water containing $20 \mathrm{~mL}$ of hydrogen peroxide $(6 \%)$ as an initiator, $1.60 \mathrm{~g}$ of ferrous ammonium sulphate as a co-initiator, and $50 \mathrm{~mL}$ of purified methyl acrylate monomer. The mixture was heated to $75^{\circ} \mathrm{C}$ for $3 \mathrm{~h}$. After the grafted product was washed with acetone, the pma-g-opefb was dried in an oven. The details of the preparation of pma-g-opefb have been previously described [9]. The final weight was measured and the grafting percentage $\left(\mathrm{P}_{\mathrm{g}}\right)$ was calculated using the following formula:

$$
\text { Grafting percentage }\left(\mathrm{P}_{\mathrm{g}}\right)=\left(\mathrm{W}_{2}-\mathrm{W}_{1}\right) / \mathrm{W}_{1} \times 100
$$

where $\mathrm{W}_{2}$ and $\mathrm{W}_{1}$ are the weights of the purified grafted product and the initial weight of the opefb, respectively.

\subsection{Modification of the Pma-g-Opefb}

A total of $1.0 \mathrm{~g}$ of pma-g-opefb was heated at $60{ }^{\circ} \mathrm{C}$ for $4 \mathrm{~h}$ with a hydrazine hydrate solution in ethanol $(15 \% \mathrm{v} / \mathrm{v})$. Then, the final product was filtered and washed several times with ethanol and dried in an oven at $60{ }^{\circ} \mathrm{C}$.

\subsection{Metal Ion Uptake Experiments Using a Batch Method}

\subsubsection{Effect of $\mathrm{pH}$}

The uptake of metal ions was carried out by placing $0.1 \mathrm{~g}$ of peh-g-opefb in a centrifuge tube of $20 \mathrm{~mL}$ of metal solution $\left(100 \mathrm{mg} \mathrm{L}^{-1}\right)$ at a controlled $\mathrm{pH}$. Sodium acetate was used as a buffer and the 
$\mathrm{pH}$ was adjusted within the range from $\mathrm{pH} 1$ to $\mathrm{pH} 6$, using various concentration of $\mathrm{HCl}$. After adsorption, the sample was filtered and the amount of remaining metal ions in the sample was determined.

\subsubsection{Effect of Initial Concentration and Temperature}

The effect of the initial concentration of metal ions in solution was evaluated by placing $0.1 \mathrm{~g}$ of peh-g-opefb fibre into $20 \mathrm{~mL}$ of metal ion solution at different concentrations $\left(50-1,000 \mathrm{mg} \mathrm{L}^{-1}\right)$ at a particular $\mathrm{pH}$. The experiment was carried out at different temperatures to determine thermodynamic parameters such as free energy $\left(\Delta \mathrm{G}^{0}\right)$, entropy $\left(\Delta \mathrm{S}^{0}\right)$, and enthalpy $\left(\Delta \mathrm{H}^{0}\right)$.

\subsubsection{Kinetic Study}

Metal ion uptake was evaluated by placing $0.1 \mathrm{~g}$ of peh-g-opefb fibre into $20 \mathrm{~mL}$ of metal ion solution $\left(100 \mathrm{mg} \mathrm{L}^{-1}\right)$ at different time intervals. After each period, the samples were filtered and the residual solutions were determined using an ICP-OES.

\section{Conclusions}

Biomass, which is more biodegradable, can be an economical alternative material for the removal of heavy metals from wastewater. In this study, opefb fibre was chemically modified to increase the capability of the biomass to adsorb heavy metal ions. Chemically modified opefb (peh-g-opefb) was successfully prepared and applied in the removal of copper ion from aqueous solutions. Maximum copper adsorption onto peh-g-opefb was achieved at around $\mathrm{pH}$ 5. The adsorption also fit the Langmuir isotherm model and the second-order kinetic model, indicating a monolayer chemisorption process. Among natural adsorbents, particularly opefb-based adsorbents, peh-g-opefb is one a potential bioadsorbent to be applied in the removal of copper ion in water and wastewater treatment.

\section{Acknowledgments}

The authors would like to thank the Ministry of Higher Education (MOHE) of Malaysia for grant ERGS/1/11/STG/UPM/01/15 and the scholarship of one of the authors and Universiti Putra Malaysia.

\section{Conflict of Interest}

The authors declare no conflict of interest.

\section{References}

1. Monier, M.; Nawar, N.; Abdel-latif, D.A. Preparation and characterization of chelating fibers based on natural wool for removal of $\mathrm{Hg}(\mathrm{II}), \mathrm{Cu}(\mathrm{II})$ and $\mathrm{Co}(\mathrm{II})$ metal ions from aqueous solutions. J. Hazard. Mater. 2010, 184, 118-125.

2. Argun, M.E.; Dursun, S.; Ozdemir, C.; Karatas, M. Heavy metal adsorption by modified oak sawdust: Thermodynamics and kinetics. J. Hazard. Mater. 2007, 141, 77-85.

3. Chang, S.H.; Teng, T.T.; Ismail, N. Extraction of $\mathrm{Cu}(\mathrm{II})$ from aqueous solutions by vegetable oil-based organic solvents. J. Hazard. Mater. 2010, 181, 868-872. 
4. Liu, R.X.; Zhang, B.W.; Tang, H.X. Synthesis and characterization of poly(acrylaminophosphoniccarboxyl-hydrazide) chelating fibre. React. Funct. Polym. 1999, 39, 71-81.

5. Ahmad Zaini, M.A.; Amano, Y.; Machida, M. Adsorption of heavy metals onto activated carbons derived from polyacrylonitrile fiber. J. Hazard. Mater. 2010, 180, 552-560.

6. Raju, G.; Ratnam, C.T.; Ibrahim, N.A.; Ab Rahman, M.Z.; Wan Yunus, W.M.Z. Graft copolymerization of methyl acrylate onto oil palm empty fruit bunch (OPEFB) fiber. Polym. Plast. Technol. Eng. 2007, 46, 949-955.

7. David, L., Rusu, M., Cozar, O., Rusu, D., Todica, M.; Balan, C. Spectroscopic and magnetic investigations of some transition metal complexes with $N$-4-methoxyphenyl- $N$-4-chlorobenzoyl hydrazide as ligand. J. Mol. Struct. 1999, 482, 149-152.

8. Bekheit, M.M.; Nawar, N.; Addison, A.W.; Abdel-Latif, D.A.; Monier, M. Preparation and characterization of chitosan-grafted-poly(2-amino-4,5-pentamethylene-thiophene-3-carboxylic acid $\mathrm{N}$-acryloyl-hydrazide) chelating resin for removal of $\mathrm{Cu}(\mathrm{II}), \mathrm{Co}(\mathrm{II})$ and $\mathrm{Ni}(\mathrm{II})$ metal ions from aqueous solutions. Int. J. Biol. Macromol. 2011, 48, 558-565.

9. Haron, M.J.; Tiansin, M.; Ibrahim, N.A.; Kassim, A.; Wan Yunus, W.M.Z. Sorption of Cu(II) by polyhydroxamic acid chelating exchanger prepared from polymethyl acrylate grafted oil palm empty fruit bunch. Bioresources 2009, 4, 1305-1318.

10. Hasar, H. Adsorption of nickel (II) from aqueous solution onto activated carbon prepared from almond husk. J. Hazard. Mater. 2003, B97, 49-57.

11. Kobya, M.; Demirbas, E.; Senturk, E.; Ince, M. Adsorption of heavy metal ions from aqueous solutions by activated carbon prepared from apricot stone. Bioresour. Technol. 2005, 96, 1518-1521.

12. Wan Ngah, W.S.; Hanafiah, M.A.K.M. Biosorption of copper ions from dilute aqueous solutions on base treated rubber (Hevea brasiliensis) leaves powder: Kinetics, isotherm, and biosorption mechanisms. J. Environ. Sci. 2008, 20, 1168-1176.

13. Dai, J.; Yan, H.; Yang, H.; Cheng, R. Simple method for preparation of chitosan/poly(acrylic acid) blending hydrogel beads and adsorption of copper (II) from aqueous solutions. Chem. Eng. J. 2010, $165,240-249$.

14. Ozcan, A.; Ozcan, A.S.; Tunali, S.; Akar, T.; Kiran, I. Determination of the equilibrium, kinetic and thermodynamic parameters of adsorption of copper (II) ions onto seeds of Capsicum annuum. J. Hazard. Mater. B 2005, 124, 200-208.

15. Gok, O.; Ozcan, A.; Erdem, B.; Ozcan, A.S. Prediction of the kinetics, equilibrium and thermodynamic parameters of adsorption of copper (II) ions onto 8-hydroxy quinolone immobilized bentonite. Colloids Surf. A Physicochem. Eng. Aspects 2008, 317, 174-185.

16. Aydin, H.; Bulut,Y.; Yerliyaka, C. Removal of copper (II) from aqueous solution by adsorption onto low-cost adsorbents. J. Environ. Manage. 2008, 87, 37-45.

17. Senthilkumar, P.; Ramalingam, S.; Sathyaselvabala, V.; Dinesh Kirupa, S.; Sivanesan, S. Removal of copper (II) ions from aqueous solution by adsorption using cashew nut shell. Desalination 2011, 266, 63-71.

18. Aloma, I.; Martin-Lara, M.A.; Rodriguez, I.L.; Balzquez, G.; Calero, M. Removal of nickel (II) ions from aqueous solutions by biosorption on sugarcane bagasse. J. Taiwan Inst. Chem. Eng. 2012, 43, 275-281. 
19. Wang, J.; Chen, T.; Li, S.; Yue, Z.; Jin, J.; He, G.; Zhang, H. Biosorption of copper (II) from aqueous solutions with rape straw. Geomicrobiol. J. 2012, 29, 250-254.

20. Kamari, A; Wan Ngah, W.S. Isotherm, kinetic and thermodynamic studies of lead and copper uptake by $\mathrm{H}_{2} \mathrm{SO}_{4}$ modified chitosan. Colloids Surf. B Biointerfaces 2009, 73, 257-266.

21. Fil, B.A.; Boncukcuoglu, R.; Yilmaz, A.E.; Bayar, S. Adsorption of Ni(II) on ion exchange resin: Kinetics, equilibrium and thermodynamic studies. Korean J. Chem. Eng. 2012, 29, 1232-1238.

22. Bhatnagar, A.; Minocha, A.K. Biosorption optimization of nickel removal from water using Punica granatum peel waste. Colloids Surf. B Biointerfaces 2010, 76, 544-548.

23. Tong, K.S.; Jain Kassim, M.; Azraa, A. Adsorption of copper ion from its aqueous solution by a novel biosorbent Uncaria gambir: Equilibrium, kinetics, and thermodynamic studies. Chem. Eng. J. 2011, 170, 145-153.

24. Ozer, A.; Gurbuz, G.; Calimli, A.; Korbahti, B.K. Investigation of nickel (II) biosorption on Enteromorpha prolifera: Optimization using response surface analysis. J. Hazard. Mater. 2008, 152, 778-788.

25. Salamatinia, B.; Kamaruddin, A.H.; Abdullah, A.Z. Removal of $\mathrm{Zn}$ and $\mathrm{Cu}$ from wastewater by sorption on oil palm tree-derived biomasses. J. Appl. Sci. 2007, 7, 2020-2027.

26. Ho, Y.S.; Ofomaja, A.E. Kinetic studies of copper ion adsorption on palm kernel fibre. J. Hazard. Mater. 2006, B137, 1796-1802.

27. Reddy, D.H.K.; Seshaiah, K.; Reddy, A.V.R.; Lee, S.M. Optimization of Cd(II), Cu(II) and Ni(II) biosorption by chemically modified Moringa oleifera leaves powder. Carbohydr. Polym. 2012, $88,1077-1086$.

28. Reddy, D.H.K.; Ramana, D.K.V.; Seshaiah, K.; Reddy, A.V.R. Biosorption of Ni(II) from aqueous phase by Moringa oleifera bark, a low cost biosorbent. Desalination 2011, 268, 150-157.

29. Pimentel, P.M.; Melo, M.A.F.; Melo, D.M.A.; Assuncao, A.L.C.; Henrique, D.M.; Silva, C.N., Jr.; Gonzalez, G. Kinetics and thermodynamics of $\mathrm{Cu}(\mathrm{II})$ adsorption on oil shale wastes. Fuel Process. Technol. 2008, 89, 62-67.

30. Padmavathy, V. Biosorption of nickel (II) ions by baker's yeast: Kinetic, thermodynamic and desorption studies. Bioresour. Technol. 2008, 99, 3100-3109.

31. Aksu, Z.; Isoglu, I.A. Removal of copper (II) ions from aqueous solution by biosorption onto agricultural waste sugar beet pulp. Process Biochem. 2005, 40, 3031-3044.

32. Ho, Y.S.; McKay, G. The kinetics of sorption of divalent metal ions onto sphagnum moss peat. Water Res. 1999, 34, 735-742.

Sample Availability: A sample of the compound is available from the authors.

(C) 2013 by the authors; licensee MDPI, Basel, Switzerland. This article is an open access article distributed under the terms and conditions of the Creative Commons Attribution license (http://creativecommons.org/licenses/by/3.0/). 